\title{
Germany and China Have Savings Gluts, the USA Is a Sump: So What?
}

\author{
Lance Taylor*
}

\section{Working Paper No. 132}

August 5 $5^{\text {th }}, 2020$

\begin{abstract}
A "global saving glut" was invented by Ben Bernanke in 2005 as a label for positive net lending (imports exceeding exports) to the American economy by the rest of the world. This trading situation had already emerged around 1980, and led to the Plaza Accord in 1985. One common explanation is based on the Mundell-Fleming IS/LM/BP model. But this model cannot be valid, since the "BP" equation is not independent of "IS." Other champions of this saving glut hypothesis rely on loanable funds theory, which is institutionally inadequate. More plausible analyses of the persistent trade imbalance can be derived from a two-country IS/LM set-up devised by Wynne Godley, a Kaleckian description of the political economy of East Asia and the United States, and dissection of the terms of trade due to W. Arthur Lewis and Luigi Pasinetti.
\end{abstract}

\section{https://doi.org/10.36687/inetwp132}

Keywords: Saving glut, net lending, IS/LM/BP, Mundell-Fleming, productivity growth, terms of trade. China, Japan

JEL Codes: E12, E16, F32, F41

\footnotetext{
* New School for Social Research. Support from INET and comments by Thomas Ferguson are gratefully acknowledged.
} 
The structure of the US economy began to shift markedly 40 or 50 years ago (details below). As part of the transformation, its international trade imbalances increased substantially. Since these changes, to summarize in the words of this paper's title, Japan, Germany, and more recently, China have exported far more than they import, creating gluts of traded goods and services. They accordingly built up stocks of "saving" which took the form of newly acquired liabilities (bonds and even money) from the rest of the world. For the USA, the process worked in reverse. The economy became an international sump with imports exceeding exports, financed by issuing liabilities or dissaving, thus turning the country into a large net debtor. Former Federal Reserve Governor Ben Bernanke was a canary in the world trade coal mine, two decades after the process started, when he announced the presence of a "global saving glut." Analysts have been perplexed by both the diagnosis and the expression ever since. This paper explores their possible meaning and coherence, employing Keynesian open economy macroeconomics. Here are takeaways.

Every economy satisfies Wynne Godley's identity setting the sum of net lending flows (increase of financial assets exceeds increase of liabilities) by four institutional sectors equal to zero, $^{2}$

$$
\begin{aligned}
& \text { (Household saving-investment })+(\text { Business saving-investment }) \\
& \quad+(\text { Government spending-income })+(\text { Imports-exports })=0
\end{aligned}
$$

This relationship follows from consistent macroeconomic accounting as in Table 1 below. In the jargon it is a version of Walras's Law.

\footnotetext{
${ }^{1}$ See Bernanke (2015) for a recent reassessment.

${ }^{2}$ The arguments herein draw heavily on Godley's ideas. Godley and Lavoie (2007) is a full presentation and Taylor (2008) provides a summary.
} 
For the world, the sum of all countries' foreign net lending must equal zero. The same is true of net borrowing or negative net lending. Country level gluts and sumps (positive and negative net lending) are unavoidable. Bernanke's label has been around for 15 years, but we will soon see from Godley's identity that the USA has been a consistent foreign net borrower for much longer (the 1985 Plaza Accord was an earlier warning of US international imbalance). This paper takes off from that observation to make four more points, first in words and then in algebra in an appendix.

\section{Key observations}

Bernanke and other new Keynesian economists have recently argued that interest rates adjust on a worldwide basis to equate business investment and household saving as uses and sources of "loanable funds." Excess potential saving worldwide allegedly forces interest rates down to a "natural" level ensuring macroeconomic balance. The problem is that empirical support for loanable funds theory is scant. In the General Theory, Keynes (1936) thought that he had extinguished loanable funds and the natural rate forever. Yet they came swooping back from the $19^{\text {th }}$ century to bewitch American new Keynesian economists in the twenty-teens. See Taylor (2016) and Storm (2017) for the reasons why they were hoaxed.

A more coherent rationale for low American interest rates is the Greenspan-BernankeYellen-Powell Federal Reserve "put" holding borrowing costs down in support of high asset prices (Taylor with Ömer, 2020). Along with similar interventions by other central banks, the put has been extended with quantitative easing and recent discussion about yield curve control. As during WWII, pegged low interest rates benefit the Treasury's accounts - a point that suddenly became compelling with the explosion of debt-financed spending to combat the corona 
virus pandemic and is likely to be important in saving an overextended private sector from itself in any recovery. In international financial markets, interest rate parity (arbitrage) and the carry trade (borrowing in one low interest rate currency to invest in another at a higher interest rate) tend to bring countries' rates together. These transactions involve jumps up or down in financial stocks held in investors' portfolios, not flows of "loanable" funds.

Mainstream applied open economy macroeconomics relies on the 60 -year-old IS/LM/BP model proposed by Mundell (1963) and Fleming (1962). ${ }^{3}$ Part of this paper's effort is devoted to showing that the model's "BP" (Balance of Payments) equation follows from consistent macro accounting. BP is not an independent restriction. The model includes three key variableseconomic activity, interest rate, and exchange rate - but it contains only two independent equations for income-expenditure ("IS") and financial ("LM") balances. One variable has to be set from outside the model, which behaves differently depending on the choice. This technical glitch - an example of model "closure" as discussed below -- becomes problematic because of the differing adjustment speeds at which the relevant variables shift. Trade flows change in a time frame measured in months or quarter-years. Interest rates and asset prices including the exchange rate are set in capital markets which adjust much more rapidly.

Godley's two-country version of IS/LM provides a vehicle for merging real economy flows and financial balance sheet dynamics. Its two relationships for two economies must be

\footnotetext{
${ }^{3}$ In the 1990s a "new open economy macroeconomics" (NOEM) unsurprisingly emerged in the academic literature, applying dynamic stochastic general equilibrium formulations to a two-country world. The narrative is that different "rates of time preference" lead the spendthrift home country to run a trade deficit to borrow (and buy imports) from its more frugal foreign counterpart. Home's exchange rate appreciates to ratify the transactions. The NOEM explanation for the spike in US net borrowing around 1980 shown in Figure 1 below has to be that the economy's time preference rate suddenly jumped upward. Perhaps the theory exaggerates the rationality behind Ronald Reagan's tax reductions. In any case, closed economy practitioners like Bernanke stick with IS/LM or something similar and drag in Mundell-Fleming when they try to deal with open economy questions.
} 
interpreted as accounting balances which clear in terms of existing institutions and modes of macroeconomic adjustment. It is worth recalling that in the General Theory, Keynes argued that capitalism is fundamentally unstable, mostly due to finance. Then he tried to provide a toolkit to deal with the problem. IS/LM is built around a few tools extracted from the kit. It is handy but ignores the emphasis on fundamental uncertainty in the $G T$. There are always unexpected shocks that derail the economy. Covid-19 is an obvious example, but there were earlier, somewhat more “endogenous" political, policy, and economic shifts around 1980.

Finally, the political economy of trade and financial flows is over-determined. To try to sort out crucial economic links. It is helpful to begin with labor productivity growth, or increases in the output to employment ratio. "Real" output of a macroeconomy or producing sector is estimated as its value of output at market prices divided by an "appropriate" price index. For given nominal output growth, real growth will be higher if the price index increases more slowly. If one sector's real output grows faster than another's, then relative prices or the terms of trade will shift against the former.

Generalizing from experiences of raw material exporters, W. Arthur Lewis (1969) argued that if productivity growth in a poor country's exporting sector is greater than the economy-wide average then the external terms of trade will tend to shift against that economy (an offsetting factor would be relatively fast productivity growth in a trading partner's export sector). That is, generalized productivity growth is desirable if a country is to avoid a deteriorating trade position. Luigi Pasinetti (1981) re-invented Lewis's idea, calling it a "principle of comparative productivity change advantage." If the principle fails in a specific country, then via deteriorating terms of trade that country forfeits benefits of productivity growth to its partners. 
Halevi and Kriesler (1998) argue that during its post-World War II growth spurt Korea violated the principle, initially relying on Japan with its high productivity growth to provide imports of intermediates and capital goods. Later, it substituted many of these imports. Around the turn of this century, China followed in turn with Japan, Korea, and Taiwan providing imports to be assembled into final goods for sale in the USA, Europe, and Asia. Meanwhile, East Asia altogether runs a trade surplus. Pasinetti (1981) pointed out that at the industry, national, or regional level, the ratio of employment to population will rise if growth of demand per capita exceeds growth of productivity. Increasing exports as a "vent for surplus" production can help satisfy this demand condition. The USA itself provides the key source of demand for Asia, meanwhile violating the productivity growth principle by itself. The economy has become increasingly dualistic, with big employment increases in low wage/low productivity sectors (Taylor with Ömer, 2020).

Both economic and not strictly economic (including military!) interventions by the USA helped create and sustain the existing trade and net lending configuration - for details see Halevi and Kriesler. The emphasis in the rest of this paper is on the economics of the American predicament.

\section{US net borrowing patterns}

Figure 1 presents shares in GDP of Godley's four sectors, with net borrowing shown as positive because it contributes to aggregate demand (National Bureau of Economic Research declared recessions are shaded). Prior to the early 1980s, the USA ran relatively small trade surpluses or deficits. Continual deficits or positive net lending flows from the rest of the world were the pattern thereafter. This initial sump event was a consequence of fiscal expansion 
(Reagan's tax cuts) and dollar appreciation of around 40\% between 1980 and 1985. By drawing capital inflows, the anti-inflationary Volcker interest rate hike was a major contributing factor to the stronger dollar.

The corresponding glut took the form of surpluses in Japan and Germany. Protests from US manufacturing including autos, grain companies, and at least some high tech companies led to the Plaza Accord of September 1985. It amounted to international coordination in support of US devaluation. That duly transpired, mostly as a consequence of the Fed selling dollars to push up foreign central banks' reserves and ultimately increase or depreciate the exchange rate $^{4}$ (see the appendix for details). In the first decade of this century, the initial phase of Bernanke's discovery of a glut, deficits were relatively large but then shrank back. Government was the principal net borrower over the entire period shown in Figure 1, with its outlays rising and receipts falling in the wake of recessions due to automatic stabilizers, Reagan in the early 1980s, and the 2008 Obama stimulus package. The household sector was the principal net lender, while business switched from borrowing to lending (investment fell below profits) after the 1980s.

\section{Figure 1}

The US economy did not just passively absorb foreign largesse. Political and policy decisions at home complemented foreign mercantilist policies in sustaining international imbalance. Driven by rising profits, the size distribution of income shifted strongly toward households in the top one percent (Taylor with Ömer, 2020). To maintain their spending (a large share on health care and education with steadily rising costs) the bottom $99 \%$ resorted to debt.

\footnotetext{
${ }^{4}$ The wording is peculiar (if the rate "depreciates" shouldn't it go down?) but standard in open economy macroeconomics. An excuse for the strange usage is that it costs a larger quantity of a depreciated or weak home currency to buy one unit of foreign currency.
} 
The ratio of household debt to GDP rose from $43 \%$ in 1982 to almost $100 \%$ in 2008 before tailing off to $77 \%$ in early 2020 . Surging debt was collateralized by rising housing prices and incentivized by the Fed's low interest rates. Much of this borrowing was directly and indirectly financed from abroad. The same is true of the government deficits shown in Figure 1.

Meanwhile the economy confronted the Triffin (1960) dilemma between the role of the dollar as the international reserve currency and the resulting need to run a current account deficit to supply the required liabilities with Treasury bonds as the major component. If the deficit were to vanish, world trade would be subject to a liquidity squeeze. With the expansion of offshore currency markets over the years, the Triffin constraint has become less rigid. Nevertheless the dollar still accounts for over $60 \%$ of international reserves, with the euro at a bit over $20 \%$. It plays a central role in trade invoicing and financing. The supply of dollar liabilities such as Treasury bonds has to grow if world trade is to do the same. ${ }^{5}$

\section{Macro balances}

Applied mainstream macroeconomics doesn't pay attention to Godley's identity. It accepts the loanable funds worldview in which business net borrowing and household net lending dominate transactions among the four sectors, ignoring the roles of government and foreign trade in contemporary economies. Godley's more interesting global IS/LM specification allows a clearer look at the complicated interactions between the exchange and interest rates.

Macroeconomic models are built around double entry accounting describing flows per unit time such as:

\footnotetext{
${ }^{5}$ Charles Kindleberger (1993) created a subfield of international political economy when he talked about hegemonic currencies such as the pound sterling in the $19^{\text {th }}$ century and the dollar in the $20^{\text {th }}$. There are recent suggestions that the USA should "abandon" hegemony (Tilford and Kundnani, 2020), consistent with the likelihood that a strong dollar adversely affects employment in "red" Trumpist states. It is not clear how that maneuver could be carried out.
} 
Demand for output (gross domestic product) $=$ its cost of production (gross domestic income)

They also include balance sheet relationships among claims such as

Value of assets $=$ Value of liabilities + net worth

In the General Theory, Keynes repudiated his earlier acceptance of loanable funds. He argued that changes in income determine how the economy responds to a potential imbalance in the first (or IS) relationship with investment, exports, and government spending on goods and services as demand "injections" and saving, taxes, and imports as "leakages" proportional to total supply. An investment shortfall will lead to lower output and income (not lower interest rates) which reduces saving. Because Keynes postulated that output responding to aggregate demand is the central macro adjustment mechanism, he had to provide a non-loanable funds theory of interest. That came from "liquidity preference" for money versus bonds in a simplified (LM) macroeconomic balance sheet.

\section{Net lending glut}

At the global level, Bernanke's glut is driven by countries with big national saving levels by households, business, and/or government. Policies can be designed to keep sectoral net lending flows high. Contractionary macro policy and/or high personal saving will tend to increase a country's trade surplus and widen the trade deficits of its partners. An economy forcing others to accept its trade surplus is putting mercantilist growth accompanied by high employment into action. The price-based mechanism for running a bigger trade deficit is exchange rate appreciation to stimulate imports and cut into exports. Policy support for offshoring and construction of global supply chains serves the same ends. Even today, Chinese 
exports are assembled from components imported from Japan, Korea, and Taiwan and sold on to the USA and other importers. ${ }^{6}$ The importing countries have adjusted internal markets to accept the rest of the world's exports.

A stronger exchange rate can be read directly from the IS/LM/BP model in which the balance of payments is treated as a third relationship imposed upon the standard IS/LM treatment. The problem is that IS/LM/BP claims too much. As shown in the appendix any single country's trade balance is determined jointly with the balances of the rest of the world's economies. Because it emerges from global macroeconomic accounting, the balance of payments (BP) is not an independent restriction on the home economy as mainstream economists like to treat it.

\section{Doing flow accounting right}

Proper double entry accounting for flows and stocks in home and foreign economies is set out in the appendix. An exchange rate (still expressed as units of home currency per unit of foreign currency) scales each country's respective price systems which are anchored by wage and import costs. In flow terms, GDP is the sum of the value (price times quantity) of outlays for consumption and investment by the private sector, government, and the rest of the world minus imports. Gross domestic income (GDI) is value added or wages plus profits. Macro balance means GDP $=$ GDI (up to a statistical discrepancy in the data). ${ }^{7}$ Home country imports are proportional to total supply (GDP plus imports). They equal foreign exports scaled from

\footnotetext{
${ }^{6}$ Data from the OECD (2018) suggest that the foreign value-added content of Chinese exports is still in the range of $20 \%$, down from more than one-quarter in 2005.

${ }^{7}$ Implicit in this accounting is a fairly stable short-term relationship between the aggregate price level (the GDP deflator, for example) and nominal wage and exchange rates. Of course, the relationship can shift over time, as growth of the US profit share of income at around $0.4 \%$ per year since 1970 demonstrates.
} 
foreign to home prices by the exchange rate. Home exports are foreign imports as determined by foreign output with prices scaled the other way. The sum of both countries' external deficits will be zero. Like the BP in IS/LM/BP, global trade balance is not an independent restriction on the world economy.

All this discussion implies that high household saving and fiscal restraint in, say, Germany have spillover effects on the rest of the world - just ask the Greeks and Italians! It does make sense, however, to do the analysis right. The relationships are straightforward. Along the IS schedule in a Keynesian foreign economy, an increase in the saving or tax rate would reduce output by the paradox of thrift. Imports would fall because incomes are falling, so for given exports the trade balance would improve. Since balances worldwide must sum to zero, the home country deficit would increase.

\section{Financial balances and interest rates}

A typical closed economy LM specification is based on "money" (a liability of the banking system) and "bonds" (often issued by the government). The private sector has (liquidity) preference between the two sorts of instruments, with "the" interest rate as a variable that adjusts to make demand equal supply for both. Walras's Law assures that if the market for one instrument clears, then so will the market for the other.

In Godley's two-country world, similar accounting applies except that there are two flavors of money and bonds and two interest rates. The bookkeeping gets a bit tricky. Home and foreign private sectors have three assets in their portfolios - the local money and the two sorts of bonds with foreign stocks scaled to home prices by the exchange rate. Sums of assets in portfolios equal private wealth. Banks determine money supplies as the sums of their holdings of local bonds and international reserves (bonds issued abroad). 
Home's net foreign assets (NFA) are the sum of foreign bonds held by the private sector and minus a similar sum of home bonds held abroad. Home wealth turns out to be total home bonds outstanding plus NFA. For example, the USA's highly negative NFA (around - \$12 trillion) shows up in the form of minimal reserves and large foreign private holdings of US liabilities combined with substantial dollar reserves held in foreign banks. For a given exchange rate, proper stock-flow accounting shows that NFA decreases (increases) over time when there is a trade deficit (surplus). All the foreign deficits in Figure 1 show why US NFA is so negative. It would jump upward with devaluation which makes foreign bond stocks more valuable in terms of local prices.

Garden variety versions of Mundell-Fleming throw a "capital account surplus" into the extraneous BP equation, thereby adding an interest rate term to changes in reserves. We can forget about all that. More realistically, in foreign portfolios, a capital movement toward home amounts to an exogenous demand shift away from foreign toward home's liabilities. The shift is a one-off jump. If the jumps cumulate over time they can destabilize the real economy. Bootstrapping their country's tiny share of world transactions, Icelandic financial engineers used international portfolio shifts toward the króna via the carry trade to turn a small current account surplus in 2002 into a deficit of $22 \%$ of GDP in 2008 . They also undertook risky investments abroad (portfolio shifts from Icelandic to foreign assets) such as "Icesave" deposit accounts in the UK and Netherlands paying high interest rates. The crash came soon thereafter.

\section{Global portfolio balance, interest and exchange rates}

In the jargon, the "closure" or the imposition of behavioral assumptions on a macroeconomic accounting framework plays a decisive role in driving how it works. The issue is 
especially important for IS-type modeling of output, employment, and inflation. Keynes's costbased pricing and demand-determined output are essential for reality-relevant macroeconomics. On the LM side, the central question is about possibilities for interest and exchange rate adjustments. Three alternative closures describe the options.

Closure 1: Suppose in old-fashioned monetarist style that banking systems determine money supplies. Also fix the exchange rate $e$. Suppose that the foreign private sector reduces its stock of local bonds and holds more liabilities issued by home's government. With this portfolio shift, excess demand for home bonds increases, which would normally be associated with a reduction in the home interest rate. The opposite applies to the foreign rate. Shifting portfolio preferences determine movements in asset returns.

Closure 2: In light of current central bank practice, a more realistic specification is to fix interest rates as well as (for the moment) the exchange rate. All money and bond demand levels will thereby be set. The banking systems each hold two stocks of bonds. Three of four money and bond excess demand functions will be independent. The obvious additional assumption is that home banks hold a fixed level of local bonds. As discussed in the appendix, the other components of money supplies will then be determined. Spillovers of foreign demands for home's liabilities will be automatically offset by monetary policy. In other words, there will be $100 \%$ sterilization of a portfolio shifts toward home bonds because fixed interest rates hold asset demands constant.

Closure 3: The alternative assumption is for home and foreign banks to fix their holdings of local bonds. The exchange rate would have to be endogenous or "float." Which way will an increase in demand for home bonds make the exchange rate move? The answer is that the rate will decrease, or appreciate. To maintain demand-supply balance for foreign bonds when 
demand for them falls, international reserves of home banks have to rise. Similarly, foreign bank reserves of home bonds must fall when their demand rises. With these shifts, the exchange rate has to fall to restore market balance. In another example, if the home banking system sells home bonds from its portfolio as the Fed did after the Plaza Accord, then the exchange rate will go up or depreciate.

\section{So what?}

Individual country external balances emerge from the general equilibrium of world trade. Unless asset preferences and/ or structures of production shift dramatically, economies with net lending gluts and sumps (or sources and sinks) are likely to retain their positions. In that sense the Bernanke glut is irrelevant. It is a side effect of a half-century of realignment in the USA and East Asia, accompanied by episodes of financial turmoil. Trade flows responded to shifts in productivity growth along the lines suggested by Lewis and Pasinetti, abetted by changing international politics and policy broadly construed.

A favorable interpretation is that America benefits from its position. Exchanging financial liabilities for imports of real goods and services is easier than producing tangible exports to pay for them. Interest rates are being held down so that the debt to GDP ratio is not likely to explode. On the other hand, good American jobs that paid high wages in high productivity sectors have been destroyed by offshoring. Part of the reason is conscious imposition of anti-labor policies over the past half-century. Currency hegemony (some would still say the dollar's exorbitant privilege) does not necessarily have to lead to decimation of labor power. Possible effects of money wages growing faster than prices would depend on where the wage increases happen. There would be a squeeze on profits which could reduce investment 
demand, resulting in lower levels of output and the trade deficit. On the other hand, low income households appear to have negative saving rates, so they might spend more than their increase in wage income. Their consumption boost might outweigh the fall in investment. Model simulations suggest that demand in the US economy may be both "low income-led" and "profitled" (Taylor with Ömer, 2020). If money wage growth is suppressed, as has been the case for four or five decades, paying more to people at the bottom of the size distribution of income is not likely to set off inflation in the form of rapid growth of both wages and prices.

International capital markets are interconnected so it is unsurprising that interest rates are low worldwide. In a broad sense, financial market Closure 1 applies, meaning that if one country's interest rate is relatively high it is likely to induce portfolio realignments that push it down. Once low rates returned post-Volcker in the USA, the Federal Reserve held them down to support the stock market. The Fed is now under pressure to keep rates low to ratify exploding Treasury debt. Perhaps the pandemic will create enough harm to ordinary Americans to drive them to increase labor militancy and spark cost-push inflation. Then the game for the interest and exchange rates could change dramatically. 


\section{Appendix}

The algebra underlying the assertions in the text is tedious but straightforward. A recurring theme is that model closure matters. Different behavioral assumptions can be imposed on accounting balances, with different outcomes.

\section{Open economy macro flows}

Table 1 lays out a symbolic social accounting matrix (SAM) describing a two-country world in flow equilibrium for output and trade. The set-up is Godley's, described more fully in Godley and Lavoie (2007) and Taylor (2008). The home country is to the left and the foreign to the right. To save space, households and business are consolidated into a single private sector. An $N$ country version would be similar, a scroll of national SAMs one beside the other with $N-1$ exchange rates built in.

\section{Table 1}

The cost decompositions in columns 1 and $1 *$ show that values of output $(P X$ in the home country) break down into value-added (price $Q$ or the GDP deflator and real quantity $V$ ) and imports which are treated as a cost because business in the first instance does the importing. The value of imports is foreign exports $E^{*}$ with price $P^{*}$ converted to home prices by the exchange rate $e$. Value-added is decomposed into wage payments $w L$ and surplus or profits $\pi Q V=\pi Y$. If the non-labor input $K$ can be valued at the output price $P$, then the rate of profit is $r=\pi Q V / P K(\pi$ is the profit share $)$. 
The second home country column shows that private income $Y$ from row B breaks down into consumption $P C$, tax payments $Z$, and saving $S_{Y}$. Presumably $S_{Y}$ is influenced by the income distribution. Government tax income from row $\mathrm{E}$ is used in the third column for spending $P G$ and saving $S_{G}$ (assumed negative in the home country). Rows $\mathrm{F}$ and $\mathrm{G}$ give flows of funds ("sources" with a positive sign, "uses" with a negative). Private saving is used to finance investment $P I$ and acquire new "T-bills" $\dot{T}$ issued by the government (interest payments are ignored). In the balance sheets in Table 2 below, home and foreign banks and the foreign private sector also hold T-bills. The corresponding flow terms are omitted in Table 1 to keep its size down but could be included by using more funds accounting balances in a fully consistent model.

In row $\mathrm{G}$, government has three sources of funds so one or two must be negative. They are saving $S_{G}$, bill issues $\dot{T}$, and a transfer $e \Delta^{*}$ from the foreign country, valued in foreign prices at $\Delta^{*}$ and translated into local prices by $e$. (The foreign government's sources of funds are saving $S_{G}^{*}$ and new bond sales $T^{*}$ which are used to finance $\Delta^{*}$ ).

The exchange rate basically scales one country's economic activity in terms of the others. The last three rows, incorporating a neat Godley trick to fit cross-border flows into the accounts of the social accounting matrix, show how the scaling works.

Home country exports $P E$ in column 4 have their sign "flipped" to negative down the column. They then are transformed to foreign prices by multiplication by $-(1 / e)$ and emerge as foreign country imports $P E / e$ in cell $\left(\mathrm{H}, 1^{*}\right)$. Similar maneuvers in rows I and $\mathrm{J}$ transform foreign exports $P^{*} E^{*}$ into home imports $e P^{*} E^{*}$ and similarly for the transfer $\left(\Delta^{*}\right.$ becomes $e \Delta^{*}$ in cell $(\mathrm{G}, 7))$.

This SAM representation raises several interesting points:

For the home country the current account deficit or "foreign saving" is equal to 


$$
S_{F}=e P^{*} E^{*}-P E=e \Delta^{*}
$$

This equation follows directly from double entry bookkeeping when import and export markets clear and the transfer goes through.

In other words, there is no balance of payments per se. Import and export levels in both countries follow from effective demand and the exchange rate. Cross-border bond movements are determined from financial markets (see below). If interest rates and dividends were included, factor payments would also have their own determinants. Godley and Lavoie emphasize that the Mundell-Fleming IS/LM/BP model makes no sense because there is no independent equation for the home country's external balance or "BP." In other words there is no direct portal through which a savings glut can penetrate the home economy - the whole world's trade balances interact.

However, there is a "duality" between the exchange rate $e$ and the transfer $\Delta^{*}$. In a demand-driven closure for a flow-flow model based on Table 1, investment and government spending would be pre-determined in both countries. Their price systems would be based on cost functions anchored on nominal wages and the exchange rate. On these assumptions, either $e$ or $\Delta^{*}$ could be pre-determined but not both. Traditional treatments of Mundell-Fleming postulate duality between $e$ and reserve changes $\dot{R}^{*}$. But of course there is no particular reason why home's current account surplus ("at world prices") $-\Delta^{*}$ should equal its change in reserves $\dot{R}^{*}-$ as discussed below capital movements can easily intervene. In one scenario, the exchange rate is set in asset markets. Then current accounts in a two-country model must be endogenous (with the same magnitudes and opposite signs).

After substituting through the SAM overall macro balance in the home country is

$$
\left(S_{Y}-P I\right)+(Z-P G)+\left(e P^{*} E^{*}-P E\right)=0
$$


saying that the sum of all institutional sectors' levels of net lending must equal zero. ${ }^{8}$ To illustrate a Keynesian closure for the home country, assume that $S_{Y}=s X, Z=z X$, and $E^{*}=$ $m X$. Then this balance can be restated as

$$
\left(s+z+e P^{*} m\right) X=P(I+G+E) .
$$

which solves for $X$. For given demand injections on the right-hand side, a higher tax or saving rate will reduce output and imports.

\section{World financial balances}

Now consider a balance sheet for a two-country world economy. Table 2 presents a financial accounting matrix or FAM for two countries in which the only assets are government bonds and money. They are held by home and foreign private sectors and banks. The accounting is an obvious open economy extension of textbook LM balances. As will be seen, its behavior under different closures can be surprising.

\section{Table 2}

The rows describe asset positions. In the first, home banks hold home government bonds $\left(T_{b}\right)$ and foreign reserves $e R^{*}$, which sum to the home money supply or $\bar{M}$. Analogously, in the third row the foreign money supply $e \bar{M}^{*}$ (valued in terms of the home currency) is the sum of local bonds $e T_{b}^{*}$ and reserves $R$. The second and fourth rows are balance sheets of the home and foreign private sectors. Their levels of wealth are $\Omega(e)$ and $\Omega^{*}(e)$ which are functions of historical accumulation and the exchange rate.

\footnotetext{
${ }^{8}$ This equation is a version of Godley's identity mentioned at the outset with business and households consolidated into one private sector.
} 
Down the columns are listed outstanding liabilities of various groups of financial actors. Thus, in the first column home government liabilities $T$ are held by home $\left(T_{b}\right)$ and foreign banks $(R)$ and private sectors ( $T_{h}$ at home and $T_{f}$ abroad). Foreign bonds valued in terms of the home currency $\left(e T^{*}\right)$ are similarly distributed to all holders in the second column. Columns one and two can be interpreted as market-clearing conditions for home and foreign government bonds. The third and fourth columns must be supplemented by clearing of money markets, $M=\bar{M}$ and $e M^{*}=e \bar{M}^{*}$

To see how the portfolio balance model hangs together, begin by observing that the FAM contains 17 variables. Of those, four are naturally pre-determined: $T$ and $T^{*}$ from previous government borrowing, and $\Omega(e)$ and $\Omega^{*}(e)$ from previous private sector saving with the caveat that wealth levels can change from capital gains or losses due to exchange rate changes. The fact that the exchange rate is simultaneously an asset and a commodity price points to the difficulties of understanding its behavior.

There are 13 "potentially endogenous" variables: home private sector asset holdings $T_{h}$, $T_{h}^{*}$, and $M$; foreign private holdings $T_{f}, T_{f}^{*}$, and $M^{*}$; home and foreign money supplies $\bar{M}$ and $\overline{M^{*}}$; central bank domestic assets $T_{b}$ and $T_{b}^{*}$; reserves $R$ and $R^{*}$; and the exchange rate $e$.

In the FAM, the row totals are always satisfied. The rows for the banks simply define the money supplies, and the rows for the private sectors must balance because all the securities out there must be held by somebody. There can, however, be excess supply levels. The demand entries in the top four rows of the first and second columns don't have to sum to bond supplies, and money demands don't have to equal supplies.

Walras's Law says that the sum of excess supply levels is zero,

$$
(\bar{M}-M)+e\left(\bar{M}^{*}-M^{*}\right)+\left(T-T_{h}-T_{f}-T_{b}-R\right)+e\left(T^{*}-T_{h}^{*}-T_{f}^{*}-T_{b}^{*}-R^{*}\right)=0 .
$$


Substituting through the balance sheets shows that Walras's Law reduces to the world wealth balance

$$
\Omega+e \Omega^{*}=T+e T^{*}
$$

which holds in and out of full equilibrium.

Taylor (2004) shows that if one bond market clears then national wealth levels follow from Walras's Law,

$$
\Omega=T+N \quad \text { and } \quad \Omega^{*}=T^{*}-N / e
$$

with $N(e)$ as the net foreign assets (NFA) of the home country,

$$
N(e)=e\left(T_{h}^{*}+R^{*}\right)-\left(T_{f}+R\right)=\left(e T_{h}^{*}-R\right)-\left(T_{f}-e R^{*}\right) \quad .
$$

Textbook versions of Mundell-Fleming say that the change in home reserves is determined historically by inward flows of finance. The assertion is not true because reserves and other entries in the Table 2 balance sheet can jump instantaneously subject to its accounting restrictions. As shown in (1), NFA is the difference between the two countries' private sector holdings of external bonds and their international reserves. After the second equals sign, the USA's highly negative NFA shows up in the form of minimal reserves $\left(e R^{*}\right)$ and large foreign private holdings of US liabilities $\left(T_{f}\right)$ combined with substantial dollar reserves abroad $(R)$. After the first equality, home's gross external assets and liabilities are $e\left(T_{h}^{*}+R^{*}\right)$ and $\left(T_{f}+R\right)$ respectively. For a given exchange rate, the difference between these two totals can only change over time via a current account deficit or surplus. The $\dot{T}$ and $T^{*}$ flow terms in a SAM in Table $1-$ appropriately expanded to include flows of funds of all the actors in Table 2 -- cumulate into stocks of bonds in the FAM. 


\section{Foreign financial movements}

A capital inflow at a point in time can be treated as a jump upward in $T_{f}$ accompanied by an offsetting decrease in $e T_{f}^{*}$. It would have to be matched at home by a jump in reserves and in the foreign country by downward jumps in money and/or domestic bond holdings. Details appear after we work through the bookkeeping.

Because $\left(T_{h}^{*}+R^{*}\right)$ and $\left(T_{f}+R\right)$ are constant in the short run, we get

$$
d N / d e=T_{h}^{*}+R^{*}>0 .
$$

Devaluation leads to an increase in home NFA.

The NFA balance can also be used in show that in each country, if the excess supply of bonds is zero then so is the excess supply of money and vice-versa. The two-country system resembles the traditional one-country liquidity preference model in which if the bond demandsupply balance clears then so will the balance for money as well.

Assume that shares of home and foreign wealth devoted to money and the two flavors of bonds satisfy the restrictions $\mu+\eta+\phi=1$ and $\mu^{*}+\eta^{*}+\phi^{*}=1$, with shares presumably depending on interest rates $i$ and $i^{*}$, the exchange rate, the level of economic activity, etc. ${ }^{9}$ Table 2 is extremely simple, but it can be used to draw interesting conclusions about the impacts of a "jump" capital movement from the foreign to the home country. Three closures of the model help fence in these outcomes.

Closure 1: As opposed to the incorrect flow-based Mundell-Fleming narrative, capital movements really are offsetting shifts of the entries in Table 2. In old-fashioned monetarist style, one closure fixes $T_{b}, T_{b}^{*}, R$, and $R^{*}$ so that money supplies in both countries are determined by

\footnotetext{
${ }^{9}$ Home and foreign portfolio shares respectively are $\mu$ and $\mu^{*}$ for money; $\eta$ and $\eta^{*}$ for home bonds; and $\phi$ and $\phi^{*}$ for external bonds.
} 
the banking authorities. Also fix the exchange rate $e$. In the home bond market $T_{h}$ and $T_{f}$ are free to vary, as are $e T_{h}^{*}$ and $e T_{f}^{*}$ in the foreign market. The standard adjustment story has $i\left(i^{*}\right)$ rising in response to an excess supply of home (foreign) bonds so that interest rates can clear both markets. The NFA balance holds after this happens, and money demand levels adjust to equilibrate the system. We have to trace through the channels via which capital movements can perturb portfolio balance. The usual outcome in a fixed exchange rate regime is that a shift in portfolio preference toward home bonds would reduce the interest rate, but it makes sense to work through the details.

Solve for interest rates in the equations which set excess supplies of bonds equal to zero,

$$
-\eta \Omega-e \eta^{*} \Omega^{*}=R+T_{b}-T
$$

and

$$
-\phi \Omega-e \phi^{*} \Omega^{*}=e\left(R^{*}+T_{b}^{*}-T^{*}\right),
$$

and then derive the rest of the variables. Changing interest rates clear these two equations. The exchange rate cannot be determined by portfolio balance when money supplies are set exogenously and interest rates (or asset prices) adjust. There is no "duality" between $R^{*}$ and $e$ as in the Mundell-Fleming model (if it were in fact valid).

To look at the effects of a capital inflow to the home country, assume a foreign portfolio shift whereby $e T_{f}^{*}$ falls by $e \delta^{*}$ and $T_{f}$ goes up by the same amount. Intuitively, excess demand for home bonds increases, which would normally be associated with a reduction in the home interest rate. ${ }^{10}$ The usual glut narrative suggests that higher foreign saving drives the home interest rate down via the BP equation. With that relationship being irrelevant, asset demand

\footnotetext{
${ }^{10}$ For the details see Taylor (2004).
} 
functions must determine the rate. In the example at hand, foreign actors (or, better, their financial computer programs) can exchange foreign for home bonds in nanoseconds.

Closure 2: In light of current central bank practice, a more realistic specification is to fix interest rates $i$ and $i^{*}$ as well as (for the moment) $e$. All money and bond demand levels will thereby be determined. Can all components of money supplies -- $T_{b}, T_{b}^{*}, R$, and $R^{*}--$ be endogenous? To check we can use the money and bond demand-supply balances (all variables on the right-hand sides are frozen historically or by the fixed values of $i, i^{*}$, and e):

Home money supply: $\quad T_{b}+e R^{*}=M$

Foreign money supply: $\quad R+e T_{b}^{*}=e M^{*}$

Home bonds: $\quad R+T_{b}=T-T_{h}-T_{f}$

Foreign bonds: $\quad e R^{*}+e T_{b}^{*}=e T^{*}-e T_{h}^{*}-e T_{f}^{*}$.

From Walras's Law we know that there are only three independent equations in this $4 \times 4$ linear system. We need another restriction, in effect to scale the supply side. The obvious assumption is that home banks' holdings $T_{b}$ of local bonds are fixed. Then $T_{b}$ determines home's reserve holdings $e R^{*}$ from the supply equation for $M$. The foreign bond balance gives $e T_{b}^{*}$ and foreign banks' reserves $R$ come from the supply equation for $e M^{*}$.

All of this leads to $100 \%$ sterilization of a capital inflow because asset demands are held constant by assumption. For the details, consider the foreign portfolio shift discussed above. From the home bond market balance, with fixed $T_{b}$ the foreign banking system's reserve holdings $R$ fall by $e \delta^{*}$. The system buys bonds $e T_{b}^{*}$ to compensate. This transaction offsets the demand shift in the foreign bond market, holding the home banks' reserves constant. Sterilization rules again. 
Closure 3: To build in a floating exchange rate, assume that foreign banks hold a given amount $e T_{b}^{*}$ of local bonds. The obvious question is which way will a capital inflow make the exchange rate move? The answer is that $e$ will decrease, or appreciate. The intuition is as follows: The capital inflow means that in the foreign bond market home's bank reserves $e R^{*}$ increase. In the home bond market, reserves $R$ of foreign banks decline. In the home money supply equation, a higher $e R^{*}$ has to be offset by a fall in $e$. By Walras's Law, foreign money supply will equal demand. Alternatively, assume that the home central bank sells from its local bond stock $T_{b}$ as did the Fed after the Plaza Accord. Then from the home bond market balance, foreign bank holdings of home bonds $R$ would have to rise. To clear the foreign money demandsupply balance, $e$ would have to increase or depreciate, the point of the exercise.

In sum, closure 1 suggests that an interest rate decrease after a capital inflow is baked into the system when the authorities target the money supply. The lower rate has nothing to do with an external savings glut.

Closure 2 asserts that with pegged exchange and interest rates, there should be a degree of automatic sterilization of the inflow.

But the floating exchange rate closure 3 says it can't be complete because appreciation is often observed. 


\section{References}

Bernanke, Ben. (2015) "Why Are Interest Rates So Low, Part 3: The Global Savings Glut," https://www.brookings.edu/blog/ben-bernanke/2015/04/01/why-are-interest-rates-so-low-part-3$\underline{\text { the-global-savings-glut/ }}$

Fleming, J. Marcus. (1962) "Domestic financial policies under fixed and floating exchange rates," IMF Staff Papers, 9: 369-379.

Godley, Wynne, and Marc Lavoie. (2007) Monetary Economics: An Integrated Approach to Credit, Money, Income, Production, and Wealth, London, Palgrave/Macmillan.

Halevi, Joseph, and Peter Kriesler. (1998 ) "History, politics, and effective demand in Asia," in Joseph Halevi and Jean-Marc Fontaine (eds). Restoring Demand in the World Economy: Trade, Finance and Technology, Northhampton MA: Edward Elgar

Keynes, John Maynard. (1936) The General Theory of Employment, Interest, and Money, London: Macmillan

Kindleberger, Charles P. (1993) A Financial History of Western Europe, New York: Oxford University Press

Lewis, W. Arthur. (1969) Aspects of Tropical Trade, 1883-1965, Stockholm: Almqvist and Wicksell

Mundell, Robert A. (1963) "Flexible Exchange Rates and Employment Policy," Canadian Journal of Economics and Political Science, 27: 509-517

OECD (2018) “Trade in Value-Added: China,” https://www.oecd.org/industry/ind/TIVA-2018China.pdf

Pasinetti, Luigi L. (1981) Structural Change and Economic Growth, Cambridge UK: Cambridge University Press 
Storm, Servaas. (2017) "Some Thoughts on Secular Stagnation, Loanable Funds, and the ZLB," https://www.ineteconomics.org/research/research-papers/some-thoughts-on-secular-stagnation$\underline{\text { loanable-funds-and-the-zlb }}$

Taylor, Lance. (2004) "Exchange Rate Indeterminacy in Portfolio Balance, Mundell-Fleming, and Uncovered Interest Rate Parity Models," Cambridge Journal of Economics, 28: 205-227

Taylor, Lance. (2008) "A foxy hedgehog: Wynne Godley and macroeconomic modeling," Cambridge Journal of Economics, 32: 639-663.

Taylor, Lance. (2016) “The 'Natural' Interest Rate and Secular Stagnation: Loanable Funds Macro Models Don't Fit Today's Institutions or Data,"

https://www.ineteconomics.org/uploads/papers/Loanable Funds Macro Models Taylor 12031 6.pdf

Taylor, Lance, with Özlem Ömer. (2020) Macroeconomic Inequality from Reagan to Trump: Market Power, Wage Repression, Asset Price Inflation, and Industrial Decline, New York: Cambridge University Press.

Tilford, Simon, and Hans Kundnani. "Is it Time to Abandon Dollar Hegemony?" https://www.foreignaffairs.com/articles/americas/2020-07-28/it-time-abandon-dollar-hegemony

Triffin, Robert. (1960) Gold and the Dollar Crisis, New Haven CT: Yale University Press. 
Figure 1: Sectoral net borrowing, 1960-2020

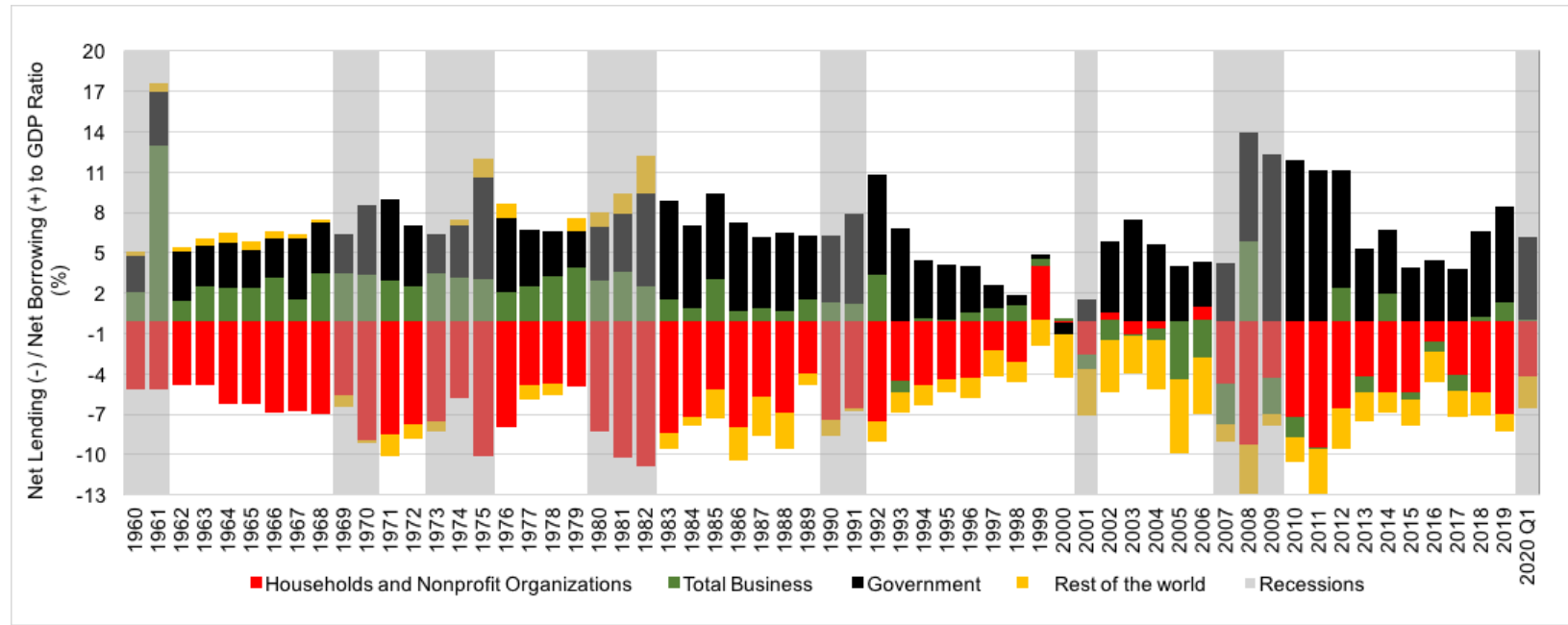


Table 1. Illustrative two-country SAM

\begin{tabular}{|c|c|c|c|c|c|c|c|c|c|c|c|c|c|c|c|c|}
\hline & $1:$ costs & $2: Y$ & $3: G$ & $4: E$ & $5: 1$ & 6:Debt & 7:Aid & 8:Totals & $1^{*}$ & $2^{*}$ & $3^{*}$ & $4^{*}$ & $5^{*}$ & $6^{*}$ & $7^{*}$ & $8^{*}$ \\
\hline C:Wages & $w L$ & & & & & & & $Y_{w}$ & $w^{*} L^{*}$ & & & & & & & $Y_{w}^{*}$ \\
\hline E: Taxes & & $Z$ & & & & & & $Y_{G}$ & & $Z^{*}$ & & & & & & $Y_{G}^{*}$ \\
\hline G: G FOF & & & $\left(S_{G}\right)$ & & & $\dot{T}$ & $e \Delta^{*}$ & 0 & & & $S_{G}^{*}$ & & & $\dot{T}^{*}$ & $-\Delta^{*}$ & 0 \\
\hline & & & & & & & & Exch. rates & & & & & & & & \\
\hline $\mathrm{H}$ & & & & $-P E$ & & & & $\times(-1 / e) \rightarrow$ & $P E / e$ & & & & & & & \\
\hline 1 & $e P^{\star} E^{*}$ & & & & & & & $\leftarrow \times(-e)$ & & & & $-P^{*} E^{*}$ & & & & \\
\hline$J$ & & & & & & & $-e \Delta^{*}$ & $\leftarrow \times(-e)$ & & & & & & & $\Delta^{*}$ & \\
\hline
\end{tabular}


Table 2. A two-country financial accounting matrix

\section{$\underline{\text { Liabilities }}$}

Home For. Home For.

Gov. Gov. bank bank Total

$\underline{\text { Assets }}$

Home bank

$T_{b} \quad e R^{*}$

$\bar{M}$

Home private

$T_{h} \quad e T_{h}^{*} \quad M$

$\Omega$

For. bank

$R \quad e T_{b}^{*}$

$e \bar{M}^{*}$

For. private

$T_{f} \quad e T_{f}^{\star}$

$e M^{*} e \Omega^{*}$

Total

$\boldsymbol{T} \quad e T^{*} \quad M \quad e M^{*}$ 